\title{
THERMO-ECONOMIC ANALYSIS AND ENVIRONMENTAL ASPECTS OF ABSORPTION REFRIGERATION UNIT OPERATION ONBOARD MARINE VEHICLES: RO- PAX VESSEL CASE STUDY
}

\author{
N R Ammar ${ }^{1}$ \\ I S Sediek ${ }^{2}$ \\ ${ }^{1}$ Alexandria University, Faculty of Engineering, Egypt \\ ${ }^{2}$ College of Maritime Transport \& Technology Arab Academy for Science, Technology \& Maritime Transport, \\ Alexandria, Egypt
}

\begin{abstract}
Marine diesel engines lose a huge amount of fuel heat content in the form of exhaust gas and jacket cooling water, especially onboard high-powered marine vehicles such as Ro-Pax ships. In this paper, the possibility of using the waste heat of marine diesel engines as a source of heat for air conditioning absorption system is investigated. The thermodynamic analysis, in addition to the environmental and economic analysis of the air condition absorption cycle operated with two heat sources using lithium bromide as absorbent, are performed using the Engineering Equation Solver (EES) software. The last 10 years have seen a steady growth in the passenger ferry and Ro-Pax market, with particularly strong growth in passenger numbers. As a case study, a Ro-Pax vessel operating in the Red Sea area is considered, regarding the profitability of using air conditioning absorption system. The results show specific economic benefits of the jacket cooling water operated absorption refrigeration unit (ARU) over the exhaust gas operated unit, with annual costs of capital money recovery of 51,870 \$/year and 54,836 \$/year, respectively. Environmentally, applying an ARU machine during cruising will reduce fuel consumption by 104 ton/year. This, in turn, will result in reducing $\mathrm{NO}_{x}, \mathrm{SO}_{x}$, and $\mathrm{CO}_{2}$ emissions with cost-effectiveness of $7.73 \$ / \mathrm{kg}, 20.39 \$ / \mathrm{kg}$, and $0.13 \$ / \mathrm{kg}$, respectively.
\end{abstract}

Keywords: ship emissions, IMO, lithium bromide-water ARU, thermodynamic analysis, economic and environmental analysis

\section{NOMENCLATURE}

h enthalpy, $\mathrm{kJ} / \mathrm{kg}$

$\mathrm{m}_{\mathrm{r}} \quad$ mass flow rate of refrigerant, $\mathrm{kg} / \mathrm{s}$

$\mathrm{m}_{\mathrm{rl}}$ mass flow rate of steam out of the evaporator, $\mathrm{kg} / \mathrm{s}$

$\mathrm{m}_{\mathrm{r} 2}$ mass flow rate of liquid carryover from the evaporator, $\mathrm{kg} / \mathrm{s}$

$\mathrm{m}_{\mathrm{ss}}$ mass flow rate of strong solution, $\mathrm{kg} / \mathrm{s}$

$m_{w s}$ mass flow rate of weak solution, $\mathrm{kg} / \mathrm{s}$

$\mathrm{v} \quad$ specific volume, $\mathrm{m}^{3} / \mathrm{kg}$

\author{
ABBREVIATIONS \\ ARU Absorption Refrigeration Unit \\ $\mathrm{CO}_{2}$ Carbon Dioxide \\ HC Hydrocarbon Emissions \\ IMO International Maritime Organization \\ $\mathrm{NO}_{\mathrm{x}}$ Nitrogen Oxide Emissions \\ PM Particulate Matter \\ $\mathrm{SO}_{\mathrm{x}}$ Sulfur Oxide Emissions \\ LiBr Lithium Bromide
}




\section{INTRODUCTION}

For the year 2012, total shipping emissions were approximately 938 million tonnes $\mathrm{CO}_{2}$ and 961 million tonnes $\mathrm{CO} 2 \mathrm{e}$ for GHGs combining $\mathrm{CO} 2, \mathrm{CH} 4$ and $\mathrm{N} 2 \mathrm{O}$. International shipping emissions for 2012 are estimated to be 796 million tonnes $\mathrm{CO} 2$ and 816 million tonnes $\mathrm{CO} 2 \mathrm{e}$ for GHGs combining $\mathrm{CO} 2, \mathrm{CH} 4$ and $\mathrm{N} 2 \mathrm{O}$. International shipping accounts for approximately $2.2 \%$ and $2.1 \%$ of global CO2 and GHG emissions on a $\mathrm{CO} 2$ equivalent (CO2e) basis, respectively [1]. This study estimates multi-year (2007-2012) average annual totals of 20.9 million and 11.3 million tonnes for NO $\mathrm{x}$ (as NO 2) and SOx (as SO2) from all shipping, respectively $[2,3]$. Moreover, recent studies of ship emissions state that the shipping-related particulate matter (PM) emissions are responsible for approximately 60,000 of cardiopulmonary and lung cancer deaths annually, with most of those deaths occurring along the coasts [4].

In addition to the abovementioned emissions, the refrigerants used onboard vessels for air conditioning and cargo cooling purposes are another source of ship emission. These refrigerants are either ozone-depleting substances, such as chlorofluorocarbons (CFCs), or their replacements, such as hydro fluorocarbons (HFCs) 1,1,1,2-tetrafluoroethane (R134a), and the mixture of pentafluoroethane, trifluoroethane and tetrafluoroethane (R404a). All these refrigerants have significant global warming potential [5]. Based on most recent statistics, the average annual loss of refrigerants from the global fleet makes the air conditioning equipment responsible for about $69.8 \%$ of the total loss of refrigerants, and $30.2 \%$ of this loss is related with the cooling equipment. Fig. 1 shows the contribution of each ship type, based on the loss of refrigerants due to air conditioning. It can be noticed that the largest amounts of loss of refrigerants are from general cargo and cruise ships [1]. Economically, there is a notified increment of fuel oil prices which presents a challenge for the marine industry.

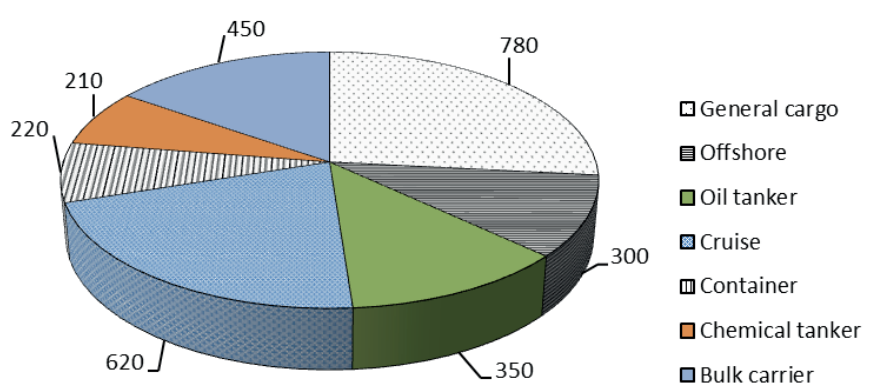

Average annual loss of refrigerants (ton/year)

Fig. 1. Refrigerant emissions due to air conditioning from different ship types [1]

\section{REGULATIONS CONTROLLING SHIP EMISSIONS}

Due to the continuous increase of emissions from ships, IMO issued a set of regulations regarding this concern in the form of the International Convention for the Prevention of Pollution from Ships (MARPOL), Annex VI. Regulation 14 limits the emissions of $\mathrm{SO}_{\mathrm{x}}$ and particulate matter (PM), while Regulation 13 and the energy efficiency design indexes limit the $\mathrm{NO}_{x}$ and $\mathrm{CO}_{2}$ emissions, respectively [6-8]. A solution which leads to the reduction of ship emissions bases on absorption refrigeration units (ARUs), which utilize engine heat losses $[9,10]$. The heat balance of the marine diesel engine, being the most frequently used prime mover on ships [11], shows that approximately more than $50 \%$ of the fuel input is lost in heat losses, including the exhaust gas (25.5\%), fresh water cooling (5.2\%), charge air cooling (16.5\%), oil cooling $(2.9 \%)$, and radiation $(0.6 \%)[9,10,12]$. Three of these heat losses can be utilized, at different temperature levels, as a heat source for ARU: exhaust gas $\left(300-600^{\circ} \mathrm{C}\right)$, charge air $\left(200^{\circ} \mathrm{C}\right)$, and jacket cooling water $\left(80-100^{\circ} \mathrm{C}\right)[12]$. Exact amounts of these heat losses will depend mainly on the cycle of operation and engine speed.

Vapor compression refrigeration systems are in common use onboard ships. These systems are powered with electric energy [13]. Although they have the advantages of high Coefficient of Performance (COP) and low purchase price, their use will be phased out with time due to their contribution to the greenhouse effect and ozone layer depletion [14]. Regulation 12 of the MARPOL convention, Annex VI, issued by IMO, states that: new installations containing ozone-depleting substances are prohibited on all ships from January 2020 [15]. On the other hand, absorption cooling is an environmentally friendly cooling method. It uses a number of refrigerant-absorbent pairs, the most common of which are water-lithium bromide and ammonia-water. They offer good thermodynamic performance [10] and can be used in single-stage and double-stage coolers, depending on the input heat source. Single-effect types are suitable for waste heat applications. The ammonia absorption cooling system can provide cooling down to $-60^{\circ} \mathrm{C}$ [16]. On the other hand, water-lithium bromide absorption coolers can be used mainly in air conditioning to cool down to temperatures above zero Celsius [12].

This paper presents the thermodynamic analysis of a singleeffect water-lithium bromide absorption refrigeration machine, starting with the cycle description and validation. The analysis includes investigating the sensitivity of cycle performance indicators. The paper also aims to study both the economic and environmental effects of using absorption refrigeration for reducing both the running costs of airconditioning during the ship cruise, and the harmful emissions. A high-speed passenger ship is used as a case study. 


\section{RO-PAX SHIP CASE STUDY}

The Ro-Pax AlKahera is one of passenger ships operating in the Red sea area. The ferry sails between the port of Duba in the Kingdom of Saudi Arabia and the port of Safaga in Egypt. The main technical data of the ferry are given in Table (1) [17]. The increased number of these ships sailing on the Red Sea have improved the maritime transport in this area by increasing the number of voyages per year, which, however, also increased the amounts of gaseous emissions $[13,18]$. These emissions have harmful impact on the Red Sea environment.

Tab. 1. Technical data of the high-speed passenger ship ALKahera [17]

\begin{tabular}{|l|l|}
\hline Ship Name & ALKahera \\
\hline Type & Ro-Pax \\
\hline IMO number & 9441776 \\
\hline Year of build & 2008 \\
\hline Flag & Egypt \\
\hline Passengers/crew & $1200 / 18$ \\
\hline Main Engine & $4 \times$ MTU 20V 8000 M71R \\
\hline Maximum Continuous Rating & $4 \times 7,200 \mathrm{~kW} @ 1,150 \mathrm{rpm} \pm 1.5 \%$ \\
\hline Service Speed & $34 \mathrm{knots}$ \\
\hline Fuel Consumption at 90\% MCR & $5.731 \mathrm{~m}{ }^{3} / \mathrm{h}$ \\
\hline Generating Sets & $4 \mathrm{x} \mathrm{MAN} \mathrm{D2866} \mathrm{LXE} \mathrm{LSAM} 46.2$ \\
\hline $\begin{array}{l}\text { Specific fuel consumption of } \\
\text { generators }\end{array}$ & $260 \mathrm{~g} / \mathrm{kWh}$ \\
\hline Air condition cooling capacity & $200 \mathrm{~kW}(4 \mathrm{units})$ \\
\hline Number of trips per year & 250 \\
\hline
\end{tabular}

The heat flow analysis for one of the main engines indicates that there are two high waste energy streams that have potential to be recovered using ARU. These two streams are the heat losses in the exhaust gas and in the jacket cooling water. With the exhaust mass flow rate of $8.7 \mathrm{~kg} / \mathrm{s}$ and the temperature of $460^{\circ} \mathrm{C}$, the exhaust gas represents $25.5 \%$ of the total input power of $16,093 \mathrm{~kW}$. On the other hand, the amount of heat transferred to the jacket cooling water is $1,091 \mathrm{~kW}$ at the mass flow rate of $26.11 \mathrm{~kg} / \mathrm{s}$, the output temperature of $85^{\circ} \mathrm{C}$, and the temperature difference of $10^{\circ} \mathrm{C}$ [19]. Based on the technical data of the case study, the Carrier absorption unit (16LJ11) with nominal cooling capacity of $264 \mathrm{~kW}$ [20] can be used onboard to cover the required refrigeration load of $250 \mathrm{~kW}$. The required mass flow rates of hot water flow and cooling water flow for the selected model are $10.4 \mathrm{~kg} / \mathrm{s}$ and $17 \mathrm{~kg} / \mathrm{s}$, respectively, while the inlet and outlet temperatures of these flows range within $95^{\circ} \mathrm{C}-75^{\circ} \mathrm{C}$ and $29.4^{\circ} \mathrm{C}-38.4^{\circ} \mathrm{C}$, respectively. The mass flow rate of cooled water is $11.4 \mathrm{~kg} / \mathrm{s}$, with inlet and outlet temperatures of $12.27^{\circ} \mathrm{C}$ and $6.7^{\circ} \mathrm{C}$, respectively. Both, the exhaust gas source and the jacket cooling waste heat source can provide the system with the required hot water mass flow rate of $10.4 \mathrm{~kg} / \mathrm{s}$, and the temperature difference between $95^{\circ} \mathrm{C}$ and $75^{\circ} \mathrm{C}$. The absorption machine is assumed to be used only during the cruise period of $8 \mathrm{hrs}$.

\section{THERMODYNAMIC ANALYSIS OF THE ABSORPTION AIR CONDITIONING CYCLE}

The most popular refrigeration and air conditioning systems are based on the vapour absorption systems. These types of systems are reliable, relatively inexpensive. A simple single-effect absorption refrigeration cycle consists of eight components: generator, condenser, evaporator, absorber, pump, two throttle valves, and heat exchanger (HX), as shown in Fig. 2 [21]. The working fluid is a mixture of water and lithium-bromide. The generator provides the cycle with the heat $\left(\mathrm{Q}_{\mathrm{g}}\right)$ to evaporate the water from the water- $\mathrm{LiBr}$ solution to high-pressure steam. The produced steam flows to the condenser, in which the thermal energy $\left(Q_{c}\right)$ is rejected to the cooling medium.

A throttle valve reduces the steam pressure and allows it to return to the vapor phase. The evaporator represents the cooling capacity $\left(\mathrm{Q}_{\mathrm{e}}\right)$ of the absorption machine. The exit low- pressure steam of the evaporator is absorbed into strong lithium-bromide solution coming from the generator by rejecting the heat energy $\left(Q_{a}\right)$ to the cooling medium. The output temperatures of the absorber and the condenser may have the same values, depending on the design of their cooling cycles [22-25]. Before the solution returns to the generator for a new cycle, its pressure at absorber exit is raised using a pump. The solutions leaving the generator and the absorber are referred to as strong and weak solutions, respectively, with reference to the percentage of lithiumbromide [26]. The solution heat exchanger preheats the weak solution using part of the heat energy of the boiling strong solution leaving the generator, which improves the cycle efficiency.

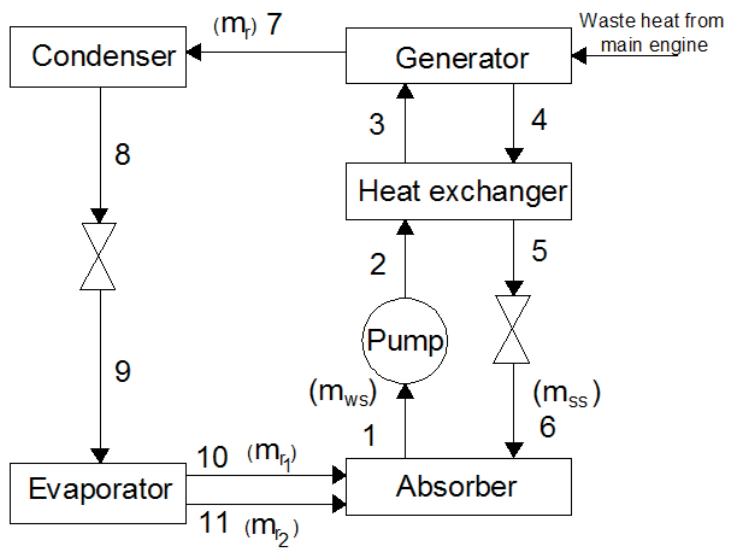

Fig. 2. Schematic diagram of the water-lithium bromide absorption cycle driven by main engine waste heat

With the intention of conduct the performance evaluation of the water-lithium bromide absorption cooler, some assumptions and initial values are to be considered. The required initial values are: the evaporator capacity $\left(Q_{e}\right)$, output temperatures of the generator, condenser, evaporator, 
and absorber, and the effectiveness of the solution heat exchanger. The basic assumptions for the thermodynamic model are: the cycle is steady-state, the refrigerants at evaporator and condenser outlets are assumed saturated vapors and saturated liquids, respectively, the flow restrictors are adiabatic, the heat loss to the surroundings is negligible, and there are no pressure losses in pipes and heat exchangers.

The mass fractions of strong and weak solutions, measured in $\mathrm{kg} \mathrm{LiBr} / \mathrm{kg}$, are $\mathrm{X}_{\mathrm{ss}}$ and $\mathrm{X}_{\mathrm{ws}}$, respectively. These fractions can be expressed in terms of temperatures $\left({ }^{\circ} \mathrm{C}\right)$ of the generator $\left(\mathrm{T}_{\mathrm{g}}\right)$, condenser $\left(\mathrm{T}_{\mathrm{c}}\right)$, absorber $\left(\mathrm{T}_{\mathrm{a}}\right)$, and evaporator $\left(\mathrm{T}_{\mathrm{e}}\right)$, using Eqs. (1) and (2) [9]. The indexes presented in Fig. 2 are used to nominate the state points in the cycle.

$$
\begin{gathered}
\mathrm{X}_{\mathrm{ss}}=\frac{49.04+1.125 \mathrm{~T}_{\mathrm{g}}-\mathrm{T}_{\mathrm{c}}}{134.65+0.47 \mathrm{~T}_{\mathrm{g}}} \\
\mathrm{X}_{\mathrm{ws}}=\frac{49.04+1.125 \mathrm{~T}_{\mathrm{a}}-\mathrm{T}_{\mathrm{e}}}{134.65+0.47 \mathrm{~T}_{\mathrm{a}}}
\end{gathered}
$$

Based on the above assumptions, the mass and energy balance equations can be applied to the absorption cycle shown in Fig.2, taking into account the operating conditions at each point. The liquid carryover from evaporator is assumed to be $2.5 \%$ [27]. Applying the energy balance equations to the absorber, the condenser, and the evaporator, gives the following expressions:

$$
\begin{gathered}
\dot{\mathrm{Q}}_{\mathrm{a}}=\dot{\mathrm{m}}_{\mathrm{r} 1} \mathrm{~h}_{10}+\dot{\mathrm{m}}_{\mathrm{r} 2} \mathrm{~h}_{11}+\dot{\mathrm{m}}_{\mathrm{ss}} \mathrm{h}_{6}-\dot{\mathrm{m}}_{\mathrm{ws}} \mathrm{h}_{1} \\
\dot{\mathrm{Q}}_{\mathrm{c}}=\dot{\mathrm{m}}_{\mathrm{r}}\left(\mathrm{h}_{7}-\mathrm{h}_{8}\right) \\
\dot{\mathrm{Q}}_{\mathrm{e}}=\dot{\mathrm{m}}_{\mathrm{r} 1} \mathrm{~h}_{10}+\dot{\mathrm{m}}_{\mathrm{r} 2} \mathrm{~h}_{11}-\dot{\mathrm{m}}_{\mathrm{r}} \mathrm{h}_{9}
\end{gathered}
$$

The ratio of the solution mass flow rate leaving the absorber to the vapor mass flow rate entering the condenser is called the cycle circulation ratio $(\mathrm{F})$.

$$
\mathrm{F}=\frac{\mathrm{m}_{\mathrm{ws}}}{\mathrm{m}_{\mathrm{r}}}
$$

The temperatures of the solution heat exchanger exit points can be determined from the energy balance (7) and the heat exchanger effectiveness $\left(\varepsilon_{\mathrm{HE}}\right)$ equation (8).

$$
\begin{gathered}
\dot{\mathrm{m}}_{\mathrm{ws}} \mathrm{h}_{2}+\dot{\mathrm{m}}_{\mathrm{ss}} \mathrm{h}_{4}=\dot{\mathrm{m}}_{\mathrm{ws}} \mathrm{h}_{3}+\dot{\mathrm{m}}_{\mathrm{ss}} \mathrm{h}_{5} \\
\varepsilon_{\mathrm{HE}}=\frac{\mathrm{T}_{3}-\mathrm{T}_{2}}{\mathrm{~T}_{4}-\mathrm{T}_{2}}
\end{gathered}
$$

The coefficient of performance (COP) measures the refrigeration cycle performance. It can be calculated using Eq. (9).

$$
\mathrm{COP}=\frac{\dot{\mathrm{Q}}_{\mathrm{e}}}{\dot{\mathrm{Q}}_{\mathrm{g}}+\dot{\mathrm{W}}_{\mathrm{p}}}
$$

where $\dot{Q}_{g}$ is the heat input to the generator. It can be determined from the generator energy balance, Eq. (10).

$$
\dot{\mathrm{Q}}_{\mathrm{g}}=\dot{\mathrm{m}}_{\mathrm{ss}} \mathrm{h}_{4}+\dot{\mathrm{m}}_{\mathrm{r}} \mathrm{h}_{7}-\dot{\mathrm{m}}_{\mathrm{ws}} \mathrm{h}_{3}
$$

$\dot{\mathrm{W}}_{p}$ is the power required to pump the solution from the exit absorber low pressure $\left(\mathrm{P}_{\mathrm{L}}\right)$ side to the generator high pressure $\left(\mathrm{P}_{\mathrm{H}}\right)$ side.

$$
\dot{\mathrm{W}}_{p}=\dot{\mathrm{m}}_{\mathrm{ws}} \mathrm{v}_{1}\left(\mathrm{P}_{\mathrm{H}}-\mathrm{P}_{\mathrm{L}}\right)
$$

First law of thermodynamics has been used to analyze and optimize inclusively the performance of absorption heat transformer operating with $\mathrm{LiBr} / \mathrm{H} 2 \mathrm{O}$ as the working pair. The mass and energy equations for the water-lithium bromide absorption cycle are analyzed using the Engineering Equation Solver (EES) software under steady-state operation. The solver has the built-in functions of thermodynamic properties of steam and water-lithium bromide mixtures. It performs multiple iterations using the mass and energy balance equations to determine the values of enthalpy (h) and mass flow rate $(\mathrm{m})$ at each point of the absorption cycle based on the input data.

The performance of steam and water-lithium bromide mixtures for the current EES model were verified using the cases provided in $[28,29]$. In addition, the current waterlithium bromide absorption cycle, modelled using the EES program, was validated on theoretical and experimental data provided by [27]. The main input parameters were: cooling capacity equal to $11 \mathrm{~kW}$, temperatures of the generator, absorber, condenser, and evaporator, equal to $90^{\circ} \mathrm{C}, 34.9^{\circ} \mathrm{C}, 30^{\circ} \mathrm{C}$, and $6.7^{\circ} \mathrm{C}$, respectively, strong and weak mass fractions amounting to $60 \%$ and $55.5 \%$ respectively, and the heat exchanger effectiveness equal to $60 \%$. Table (2) compares the results of the current study with those published in the literature. The maximum percentage difference between these results was $1.13 \%$ for the cycle COP.

Tab. 2. Cycle validation

\begin{tabular}{|l|c|c|c|}
\hline Parameter & $\begin{array}{c}\text { Published } \\
\text { study [27] }\end{array}$ & Present study & $\begin{array}{c}\text { Percentage } \\
\text { difference (\%) }\end{array}$ \\
\hline Condenser (kW) & 10.78 & 10.90 & +1.11 \\
\hline Generator (kW) & 14.2 & 14.35 & +1.05 \\
\hline Absorber $(\mathrm{kW})$ & 13.42 & 13.44 & +0.15 \\
\hline Pump (kW) & 0.29 & 0.289 & -0.34 \\
\hline COP & 0.704 & 0.696 & -1.13 \\
\hline
\end{tabular}




\section{ENVIRONMENTAL AND ECONOMIC ANALYSIS OF THE ABSORPTION AIR CONDITIONING CYCLE}

The reduction in the quantity of annual emission during cruise after applying ARU $\left(\mathrm{ER}_{\mathrm{ARU}}\right)$ can be calculated using Eq. (12)

$$
\mathrm{ER}_{\mathrm{ARU}}=\mathrm{P}_{\mathrm{E}} \cdot \mathrm{T}_{\mathrm{S}} \cdot \mathrm{F}_{\mathrm{e}}
$$

where $\mathrm{P}_{\mathrm{E}}$ is the saved electric power in $\mathrm{kW}$ at cruise, $\mathrm{T}_{\mathrm{s}}$ is the number of sailing hours per year, and $\mathrm{F}_{\mathrm{e}}$ is the emission factor for the engine in ( $\mathrm{g} / \mathrm{kWh})$.

ARU can be considered as one of the emission reduction measures. The annual emission cost-effectiveness after applying ARU onboard the ship $\left(\mathrm{ACE}_{\mathrm{ARU}}\right)$ can be calculated with respect to the reduction of each type of pollutant emissions using Eq. (13) [6, 30].

$$
\mathrm{ACE}_{\mathrm{ARU}}=\frac{\mathrm{C}_{\mathrm{ti}}}{\mathrm{ER}_{\mathrm{ARU}}}
$$

where, $\mathrm{C}_{\mathrm{ti}}$ is the total annual cost of ARU machine which includes capital, operating, and maintenance costs in (\$/year).

The total annual installation cost $\left(\mathrm{C}_{\mathrm{ti}}\right)$ of the ARU system depends on the annual initial money recovery (AMR), the installation cost $\left(\mathrm{C}_{\text {ins. }}\right)$, the annual maintenance and operating cost $\left(\mathrm{C}_{\mathrm{m \& o}}\right)$, and the heat exchanger cost $\left(\mathrm{C}_{\mathrm{HE}}\right)$ in the case of the exhaust gas operated ARU. $C_{t i}$ can be calculated using Eq. (14)

$$
\mathrm{C}_{\mathrm{ti}}=\mathrm{AMR}+\mathrm{C}_{\mathrm{ins} .}+\mathrm{C}_{\mathrm{m} \& o}+\mathrm{C}_{\mathrm{HE}}
$$

The annual money recovery (AMR) when applying ARU depends on the unit cost (UC), the expected ship age after applying the absorption system (n), and the interest rate (i) [31]. AMR can be calculated using Eq. (15).

$$
A M R=U C \times \frac{i(1+i)^{n}}{(1+i)^{n}-1}
$$

Fuel saving due to the use of ARU instead of CRU during sailing $\left(\mathrm{m}_{\mathrm{fs}}\right)$ depends on the electric power saved during the trip $\left(\mathrm{P}_{\mathrm{E}}\right)$ in $(\mathrm{kW})$, the specific fuel consumption of the generator $\left(b_{e g}\right)$ in $(g / k W h)$, and the number of sailing hours per year $\left(\mathrm{T}_{\mathrm{s}}\right.$ ). Thus, $\mathrm{m}_{\mathrm{fs}}$ can be calculated using Eq. (16).

$$
\mathrm{m}_{\mathrm{fs}}=\mathrm{b}_{\mathrm{eg}} \cdot \mathrm{P}_{\mathrm{E}} \cdot \mathrm{T}_{\mathrm{s}}
$$

The fuel cost saving $\left(\mathrm{C}_{\mathrm{fs}}\right)$ will depend on three main factors, including: the amount of saved fuel, fuel prices $\left(\mathrm{C}_{\mathrm{f}}\right.$ in $\$ /$ ton $)$, and the yearly fuel price change (PI). This can be expressed as the following equation:

$$
\mathrm{C}_{\mathrm{fs}}=\mathrm{m}_{\mathrm{fs}} \cdot C_{f} \cdot[1 \pm \mathrm{PI}]^{n}
$$

\section{RESULTS AND DISCUSSION}

The results compare the performance of two ARU waste heat recovery systems. The first system uses the main engine exhaust gas as the heat source for the generator, while the second uses the jacket cooling water. In the study, the operating temperatures of the condenser and the absorber were assumed within the range from 20 to $40^{\circ} \mathrm{C}$, based on the used cooling water conditions $[9,32]$. The assumed hot water temperatures were within the range of $95^{\circ} \mathrm{C}$ to $86^{\circ} \mathrm{C}$, with the average generator output temperature of $90.5^{\circ} \mathrm{C}$, for the exhaust gas operated generator, and within the range of $85^{\circ} \mathrm{C}$ to $75^{\circ} \mathrm{C}$, with the average generator output temperature of $80^{\circ} \mathrm{C}$, for the jacket cooling water operated generator. This was based on the main engine heat balance data and the selected carrier model for ARU unit. The evaporator temperature for this unit is $6.7^{\circ} \mathrm{C}[20]$. The generator temperature for a single-stage water-lithium bromide ARU unit was assumed within the range from $75^{\circ} \mathrm{C}$ to $120^{\circ} \mathrm{C}[21,33,34]$. The cooling capacity of the ARU unit was assumed equal to $250 \mathrm{~kW}$ based on the ALKahera high-speed passenger ship technical data shown in Table (1).

The results include the effect of condenser and evaporator temperatures on the performance of the absorption refrigeration cycle. In addition, the environmental and economic results of applying the above two waste heat recovery operated ARU machines onboard the ship selected as the case study are discussed.

\section{THERMODYNAMIC RESULTS}

Although ARU consists of many components, only its three components: condenser, absorber and evaporator, play a key role in its applicability onboard ships. It is noteworthy that the effects of the condenser and the absorber on refrigeration cycle performance reveal nearly similar trends, which also coincide with those recorded in the published paper [35]. In this section, the effect of condenser and evaporator temperatures on the water- $\mathrm{LiBr}$ refrigeration cycle is studied as follows:

\section{Effect of ARU condenser temperature}

The effect of the condenser temperature on the performance of the water-lithium bromide refrigeration cycle is examined by changing $\mathrm{T}_{\mathrm{c}}$ and $\mathrm{T}_{\mathrm{g}}$, while simultaneously maintaining $\mathrm{T}_{\mathrm{a}}=30^{\circ} \mathrm{C}$, and $\mathrm{T}_{\mathrm{e}}=6.7^{\circ} \mathrm{C}$. Fig. 3 shows the effect of condensation temperature on the cycle $\mathrm{COP}$ and the required generator power for both exhaust gas and jacket cooling water heat sources. The required generator power increases significantly with the increasing condensation temperature. Its maximum values change from $325 \mathrm{~kW}$ for the generator operated on jacket cooling water, to $315 \mathrm{~kW}$ for the generator operated on the exhaust gas. In contrast, the cycle COP decreases with the increase of condenser temperature. This COP trend coincides with the experimental results presented in [36]. 


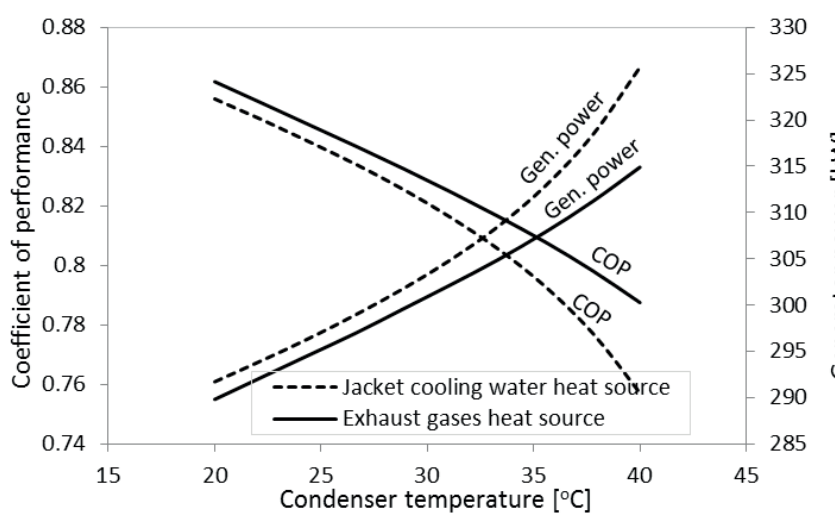

Fig. 3. Effect of condensation temperature on COP and generator power

Variations of absorber power and strong solution mass fraction at different output condensation and generation temperatures are illustrated in Fig. 4 . As the condensation temperature increases, the strong solution mass fraction decreases, while the absorber power increases. As a result of the increase of condensation temperature by $20^{\circ} \mathrm{C}$, the strong solution mass fraction increases by an average of $6.8 \%$ when the generator operates on the exhaust gas heat source, compared to the jacket cooling heat source. This is due to the increased exit generator temperature from $80^{\circ} \mathrm{C}$ to $90.5^{\circ} \mathrm{C}$. On the other hand, the absorber power decreases by approximately $0.7 \%$ when the solution mass fraction increases by $6.8 \%$ at the same condensation temperature. This is due to the increased strong solution mass flow rate from $0.237 \mathrm{~kg} / \mathrm{s}$ to $0.30 \mathrm{~kg} / \mathrm{s}$.

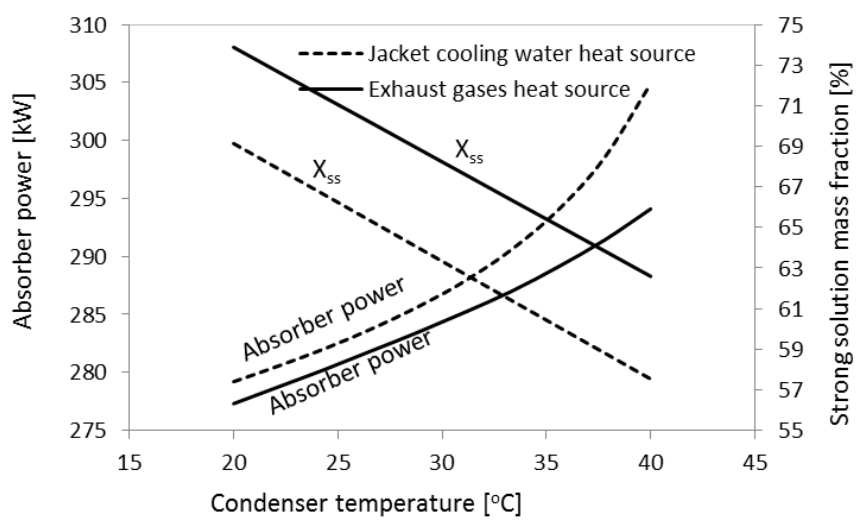

Fig. 4. Effect of condensation temperature on absorber power and strong solution mass fraction

\section{Effect of ARU evaporator temperature}

The influence of the evaporator temperature on the performance of the water-lithium bromide refrigeration cycle is studied in this section. This analysis is made by varying $\mathrm{T}_{\mathrm{e}}$ and $\mathrm{T}_{\mathrm{g}}$, while simultaneously keeping $\mathrm{T}_{\mathrm{a}}$ and $\mathrm{T}_{\mathrm{c}}$ at $30^{\circ} \mathrm{C}$. The temperature of the refrigerant leaving the evaporator varies from $5^{\circ} \mathrm{C}$ to $25^{\circ} \mathrm{C}$ at the two generator temperatures of $90.5^{\circ} \mathrm{C}$ and $80^{\circ} \mathrm{C}$. Fig. 5 shows the effect of evaporation temperature on the circulation ratio and the required pump power. We can observe that both quantities decrease as the evaporator temperature increases. The required pump power of the jacket cooling water operated generator is lower than that of the exhaust gas. As a result, the economic performance of the absorption cooling machine is improved with the increased evaporator temperature, especially when the temperature of the available heat source is low. This coincides with the results published in [32].

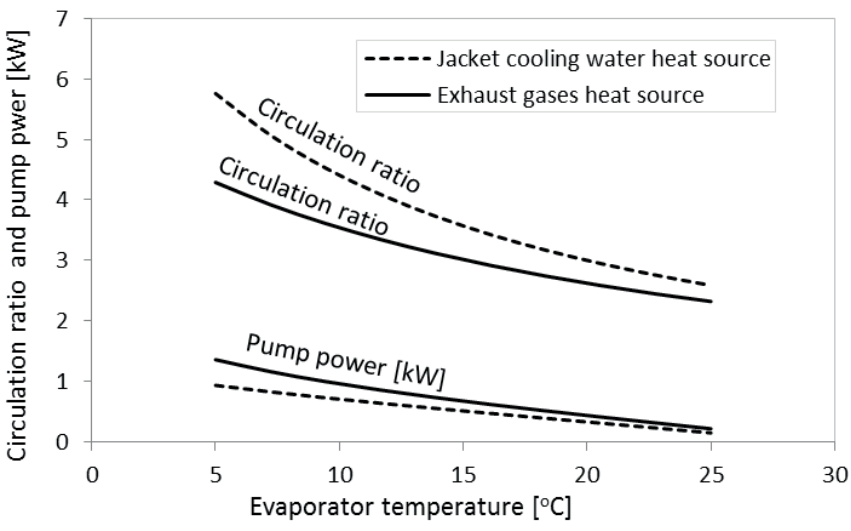

Fig. 5. Effect of evaporation temperature on circulation ratio and pump power

In case of the evaporation temperature is increased, while maintaining both $\mathrm{T}_{c}$ and $\mathrm{T}_{\mathrm{a}}$ at $30^{\circ} \mathrm{C}$, the mass fraction of the absorber power and the weak solution mass fraction decrease. At the same time, the strong solution mass fractions are kept at the same levels, as shown in Fig. 6. The decreasing power and mass fraction take their lowest values when the evaporation temperature reaches its condensation temperature. In addition, the mass flow rates of both the strong and the weak solution start with high values, which then decrease by $55.77 \%$ and $67.09 \%$, respectively, at the end of the considered evaporator temperature range, for the generator exit temperature of $80^{\circ} \mathrm{C}$. These reductions are equal to $46.65 \%$ and $60 \%$, respectively, when the exit generator temperature is increased to $90.5^{\circ} \mathrm{C}$. These results also indicate that the absorber power for the jacket cooling water and the exhaust gas heat sources is nearly the same at high evaporator temperatures, starting from $15^{\circ} \mathrm{C}$.

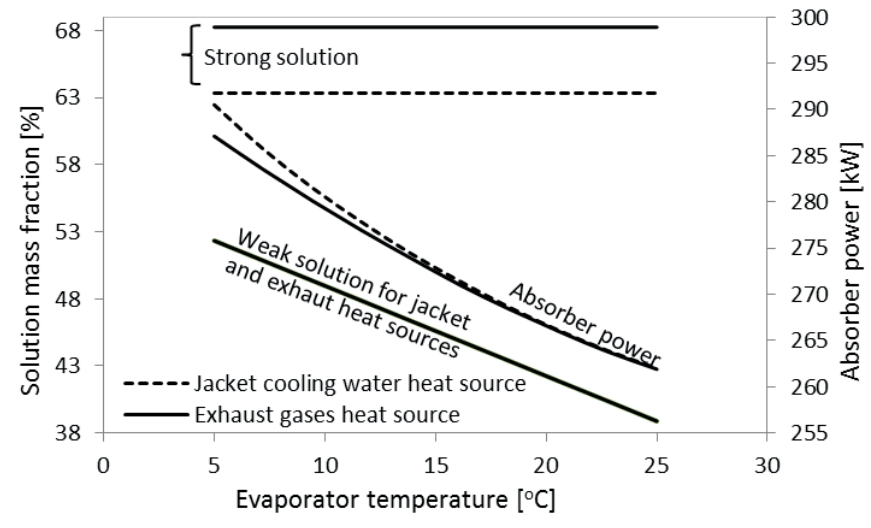

Fig. 6. Effect of evaporation temperature on solution mass fractions and absorber power 


\section{ENVIRONMENTAL AND ECONOMIC RESULTS}

Practically, using ARU will lead to savings in the required generator power, and consequently to the reduction of both fuel consumption and emissions. For the examined case study, using ARU will save fuel consumption by 104 ton/year, at the fuel price of $720 \$ /$ ton [37]. This saving will result in dispensing with one of the diesel generators during ship cruise. The emission factors for the high- speed diesel engines fueled with marine diesel oil (MDO), with $1.0 \%$ sulfur, are respectively equal to $10.81 \mathrm{~g} / \mathrm{kWh}, 4.1 \mathrm{~g} / \mathrm{kWh}, 0.3 \mathrm{~g} / \mathrm{kWh}, 645 \mathrm{~g} / \mathrm{kWh}$, and $0.2 \mathrm{~g} / \mathrm{kWh}$ for $\mathrm{NO}_{x}, \mathrm{SO}_{x}, \mathrm{PM}, \mathrm{CO}_{2}$, and $\mathrm{HC}$ emissions, during cruise $[38,39]$. Based on these factors, the emission rates in $\mathrm{kg} / \mathrm{min}$ during trip for each main engine can be calculated as shown in Fig. 7. For the case study, the $\mathrm{SO}_{\mathrm{x}}$ and $\mathrm{NO}_{\mathrm{x}}$ emission rates are $0.3936 \mathrm{~kg} / \mathrm{min}$ and $1.038 \mathrm{~kg} / \mathrm{min}$, respectively, during cruise mode for each main engine. These rates should be compared with IMO 2020 and IMO 2016 (Tier III) rates of $0.24 \mathrm{~kg} / \mathrm{min}$ and $0.287 \mathrm{~kg} / \mathrm{min}$, respectively. The same can be done for the maneuvering and stand-by modes. From Fig. 7, both $\mathrm{NO}_{\mathrm{x}}$ and $\mathrm{SO}_{\mathrm{x}}$ emission rates of the high-speed diesel engine will not be combatable with the new IMO emission limits during ship cruise. This highlights the importance of using ARU to meet the stringent IMO regulations.

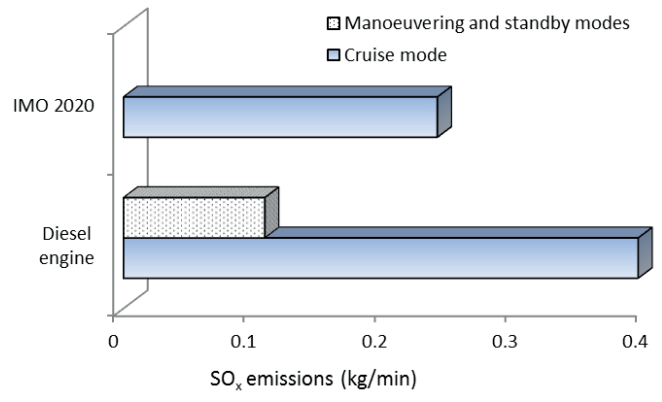

Fig. 7. Comparing emissions of case study vessel with IMO limits

Environmental benefits of the use of ARU unit become clear when comparing the yearly emission reduction in ton/ year after applying the ARU unit, as shown in Fig. 8. The yearly emissions from the main engine are 102.7 ton/year, 38.87 ton/year, 2.981 ton/year, 6115 ton/year, and 1.987 ton/ year for $\mathrm{NO}_{\mathrm{x}}, \mathrm{SO}_{\mathrm{x}}, \mathrm{PM}, \mathrm{CO}_{2}$, and $\mathrm{HC}$, respectively. Applying the ARU unit during cruise mode will reduce these emissions down to 4.32 ton/year, 1.64 ton/year, 0.12 ton/year, 285 ton/ year, and 0.08 ton/year, respectively.
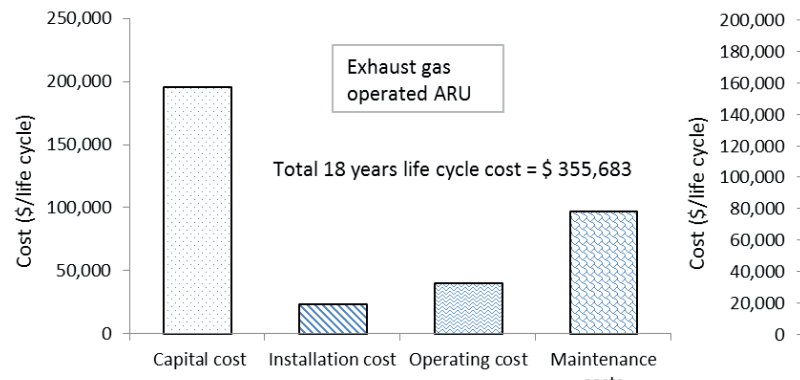

Fig. 9. Total lifecycle cost elements for waste-heat operated ARU units over remaining 18 years of operation

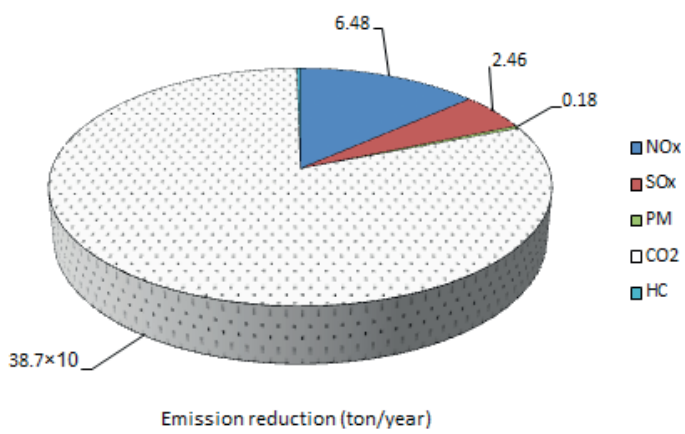

Fig. 8. Yearly emission reduction after applying $A R U$

Economically, the application of the ARU unit can be judged from the annual installation costs and its recovery period. The capital cost of the ARU unit ranges from $500 \$ /$ $\mathrm{kW}$ to $700 \$ / \mathrm{kW}$, with the installation cost amounting to $12 \%$ of this cost. The annual operating and maintenance costs are $8 \$ / \mathrm{kW}$ and $0.008 \$ / \mathrm{kWh}$, respectively [13, 27, 40]. For the application of the carrier absorption unit (16LJ11), the capital and installation costs are $\$ 218,817$ and $\$ 206,976$, at yearly fuel saving of 52,000 $\$ /$ year, for the exhaust gas and jacket cooling water operated ARU units, respectively. The heat exchanger cost is the added cost only for the exhaust gas operated ARU unit, and not for the jacket cooling water operated unit. It adds extra expenses to the total ARU cost, but it improves the performance of the generator, compared to direct use of exhaust gas [13]. The initial heat exchanger
cost is $\$ 10,572$ which presents $5.7 \%$ of the capital cost of the exhaust gas operated ARU unit. The total lifecycle cost (LCC) of the two ARU units depends on the ship age and the working years remaining after the installation. Fig. 9 shows the LCC for the exhaust gas and jacket cooling water operated ARU units over 18 years of operation, assuming the average ship age of 28 years $[6,41]$. The capital cost of the jacket cooling water operated ARU unit is $\$ 184,800$, while that of the exhaust gas operated ARU is $\$ 195,372$, representing $57.38 \%$ of LCC for this unit. For the jacket cooling water operated ARU unit, the operating and maintenance costs are $\$ 38,016$ and $\$ 76,032$, respectively, representing $11.8 \%$ and $23.6 \%$ of LCC. Therefore, evaluating the total LCC will help making decision about purchasing an ARU unit. The decision will be based on the unit which minimizes energy and maintenance costs. 
In addition, the economic decision for applying the ARU unit should consider the time required for money recovery. Fig. 10 shows the yearly fuel saving cost and the annual cost for capital recovery with payback periods for the exhaust gas operated ARU unit. The payback periods should be compared with the available economic life of the ship. For the case study, the annual costs for capital money recovery are 54,836 \$/year and 51,870 \$year for the exhaust gas and jacket cooling water operated ARU units, respectively, at $\mathrm{i}=10 \%$, and the payback period of 6 years. Moreover, the fuel saving cost has to be considered in order to evaluate the total economic benefits of applying the ARU unit onboard the case study ship. The annual fuel saving cost at the end of 18 years of ship operation will amount to $\$ 127,478$, at $3 \%$ fuel price increment.
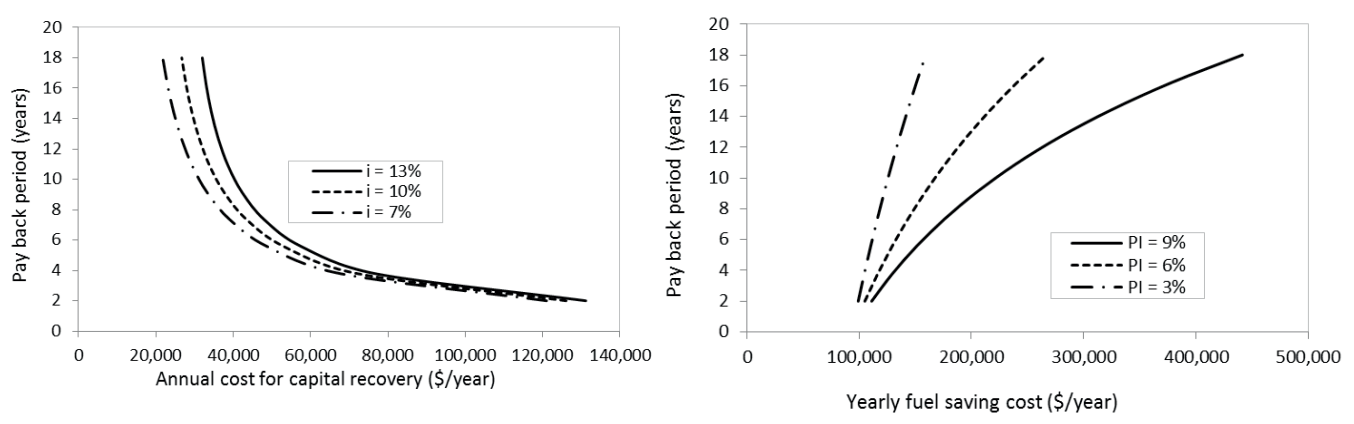

Fig. 10. Annual capital recovery and fuel saving cost after applying the exhaust gas operated ARU unit

On the other hand, calculating the annualized costeffectiveness for each reduction in emissions will show extra eco-environmental benefits of applying the ARU unit for the main engine. Fig. 11 evaluates the cost-effectiveness of each emission reduction. The lower the annual emission costeffectiveness, the higher the economic benefit of reducing the emission parameter. The effectiveness costs of reducing $\mathrm{SO}_{\mathrm{x}}$ emissions are $20.39 \$ / \mathrm{kg}$ and $19.25 \$ / \mathrm{kg} \$ / \mathrm{kg}$ for exhaust gas and jacket cooling water operated ARU units, respectively, as shown in Fig. 11. $\mathrm{NO}_{\mathrm{x}}$ emissions will be reduced with costeffectiveness of $7.73 \$ / \mathrm{kg}$ and $7.30 \$ / \mathrm{kg}$, respectively. The most economic cost-effectiveness option for applying the ARU unit is for the reduction of $\mathrm{CO}_{2}$ emissions, which are reduced by 258 ton/year, with cost-effectiveness of $0.13 \$ / \mathrm{kg}$.

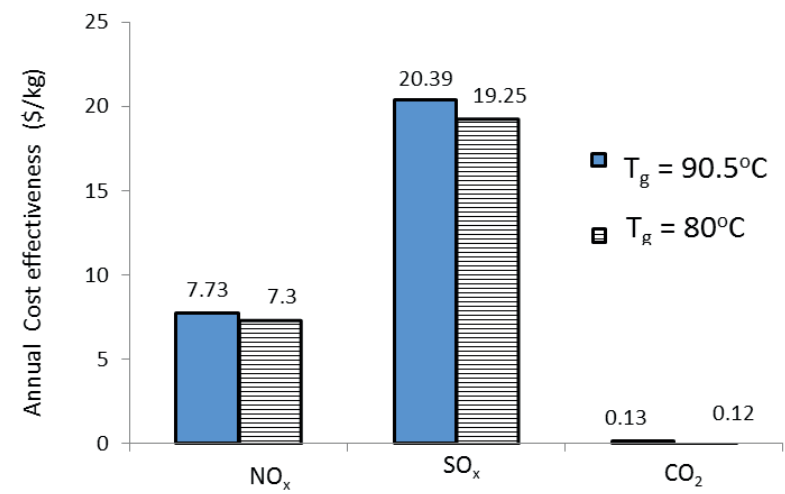

Fig. 11. Annual NOx, SOx and CO2 emission reduction cost-effectiveness after applying ARU unit

\section{CONCLUSIONS}

The performance of a water-lithium bromide absorption cooling machine installed onboard a ship has been analyzed. As a case study, a Ro-Pax vessel operating in the Red Sea area was investigated. The above performance was discussed from thermodynamic, environmental, and economic points of view. The main conclusions can be summarized as follows:

- With reference to the thermodynamic analysis, both exhaust gas and jacket cooling water heat sources can provide the required heat for the ARU generator to cover the required cooling capacity of $200 \mathrm{~kW}$.

- From the environmental point of view, the application of ARU machine will decrease fuel consumption by 104 ton/year. This will reduce the $\mathrm{NO}_{x}$ and $\mathrm{SO}_{x}$ emissions by 4.324 ton/ year and 1.64 ton/year, respectively. The highest reduction will be in $\mathrm{CO}_{2}$ emissions, by 258 ton/year. - According to the economic results, using exhaust gas and jacket cooling water waste-heat sources for ARU machines will annually save 127,478 at the end of the expected ship lifecycle, at 3\% fuel price increment. Based on the total lifecycle cost analysis, the jacket cooling water operated ARU unit is more economical than that operated with exhaust gas, at capital and installation costs of $\$ 218,817$ and $\$ 206,976$, respectively. This will lead to the reduction in $\mathrm{SO}_{\mathrm{x}}, \mathrm{NO}_{\mathrm{x}}$, and $\mathrm{CO}_{2}$ emissions with cost-effectiveness of $20.39 \$ / \mathrm{kg}, 7.73 \$ /$ $\mathrm{kg}$, and $0.13 \$ / \mathrm{kg}$, respectively. Both analyzed systems can be considered an economic option for newly built ships or currently operated ships with available payback period of six years.

\section{ACKNOWLEDGMENT}

Special thanks are due to all the companies that provided essential information, especially MARIN-TEK, MTU. In addition, many appreciations are due to staff of Alkahera Company for Ferries and Maritime Transport for their help, especially Eng. Tharwat Assad, the technical manager for his help.

\section{REFERENCES}

1. IMO, Third IMO GHG study 2014. Executive summary and final report, MEPC 67/6/INF.3. 2014: International Maritime Organization, London.

2. Peters, G.P., et al., The challenge to keep global warming below 2 [deg]C. Nature Clim. Change, 2013. 3(1): p. 4-6. 
3. Boden, T.A., R.J. Andres, and G. Marland, in Global, Regional, and National Fossil-Fuel CO2 Emissions, Period of Record 1751-20102013, Carbon Dioxide Information Analysis Center (CDIA C), U.S. department of energy.

4. Salvatore, A., Ocean sustainability in the 21 century. 2015: ISBN 978-1-107-10013-8, Cambridge University press, United Kingdom. .

5. EC. European Union (EU) legislations to control fluorinated greenhouse gases (F-gases). 2017. Available: https:// ec.europa.eu/clima/policies/f-gas/legislation_en (Accessed 5 July 2017).

6. Ammar, N.R. and I.S. Seddiek, Eco-environmental analysis of ship emission control methods: Case study RO-RO cargo vessel. Ocean Engineering, 2017. 137: p. 166 - 173.

7. El Gohary, M.M., N.R. Ammar, and I.S. Seddiek, Steam and SOFC based reforming options of PEM fuel cells for marine applications. Brodogradnja, 2015. 66(2)(2): p. 61-76.

8. Seddiek, I.S., An overview: Environmental and economic strategies for improving quality of ships exhaust gases. International Journal of Maritime Engineering, 2015. 157: p. 53-64.

9. Salmi, W., et al., Using waste heat of ship as energy source for an absorption refrigeration system. Applied Thermal Engineering, 2017. 115: p. 501-516.

10. Cao, T., et al., Performance investigation of engine waste heat powered absorption cycle cooling system for shipboard applications. Applied Thermal Engineering, 2015. 90: p. $820-830$.

11. Eyring, V., et al., Emissions from international shipping: 2. Impact of future technologies on scenarios until 2050. Journal of Geophysical Research: Atmospheres, 2005. 110(D17): p. D17306, doi:10.1029/2004JD005620.

12. Ouadha, A. and Y. El-Gotni, Integration of an ammoniawater absorption refrigeration system with a marine diesel engine: A thermodynamic study. Procedia Computer Science, 2013. 19: p. 754-761.

13. Seddiek, I.S., M. Mosleh, and A.A. Banawan, Thermoeconomic approach for absorption air condition onboard high-speed crafts. International Journal of Naval Architecture and Ocean Engineering, 2012. 4(4): p. 460-476.

14. Riffat, S.B. and G. Qiu, Comparative investigation of thermoelectric air-conditioners versus vapour compression and absorption air-conditioners. Applied Thermal Engineering, 2004. 24(14-15): p. 1979-1993.
15. IMO, Prevention of air pollution from ships. Second IMO GHG Study, MEPC 59, 2009.

16. Táboas, F., M. Bourouis, and M. Vallès, Analysis of ammonia/water and ammonia/salt mixture absorption cycles for refrigeration purposes in fishing ships. Applied Thermal Engineering, 2014. 66(1-2): p. 603-611.

17. Austral. AUTO EXPRESS 88. 2008. Available: http:// www.austal.com/sites/default/files/data-sheet/Auto_ Express_88_340_and_341.pdf (Accessed 15 June 2017).

18. Seddiek, I.S., Application of fuel-saving strategies onboard high-speed passenger ships. Journal of Marine Science and Technology, 2016. 21(3): p. 493-500.

19. MTU. Marine Diesel Engines 20V 8000 M71R/71/71L for Fast Vessels with High Load Factors (1B) 2017. Available: https://mtu-online-shop.com/media/files_public/ c9c121a2e1f6df696c45fdbe3ca03489/3231631_MTU_ Marine_spec_20V8000M71-R-L_1B_1_14.pdf (Accessed 16 April 2017.

20. Carrier. Single-Effect Hot Water-Fired Absorption Chillers (16LJ 11-53). 2016. Available: https://climamarket.bg/ wp-content/uploads/Tech-Spec-Carrier-16LJ.pdf(Accessed 10 May 2017).

21. Srikhirin, P., S. Aphornratana, and S. Chungpaibulpatana, A review of absorption refrigeration technologies. Renewable and Sustainable Energy Reviews, 2001. 5(4): p. 343-372.

22. Yan, X., et al., A novel absorption refrigeration cycle for heat sources with large temperature change. Applied Thermal Engineering, 2013. 52(1)(1): p. 179- 186.

23. Hong, D., et al., A novel absorption refrigeration cycle. Applied Thermal Engineering, 2010. 30 (14-15): p. 2045-2050.

24. Onan, C., D.B. Ozkan, and S. Erdem, Exergy analysis of a solar assisted absorption cooling system on an hourly basis in villa applications. 2010. 35 (12): p. 5277 - 5285.

25. Adewusi, S.A. and S.M. Zubair, Second law based thermodynamic analysis of ammonia-water absorption systems. Energy Conversion and Management, 2004. 45(1516): p. 2355 - 2369.

26. ASHRAE, Handbook of fundamentals, 2009, Atlanta: ASHRAE.

27. Florides, G.A., et al., Design and construction of a $\mathrm{LiBr}$ water absorption machine. Energy Conversion and Management, 2003. 44(15): p. 2483-2508. 
28. Pátek, J. and J. Klomfar, A computationally effective formulation of the thermodynamic properties of $\mathrm{LiBr}-\mathrm{H} 2 \mathrm{O}$ solutions from 273 to $500 \mathrm{~K}$ over full composition range. International Journal of Refrigeration, 2006. 29(4): p. 566-578.

29. Pátek, J. and J. Klomfar, A simple formulation for thermodynamic properties of steam from 273 to $523 \mathrm{~K}$, explicit in temperature and pressure. International Journal of Refrigeration, 2009. 32(5): p. 1123-1125.

30. ICF. Towboat emission reduction feasibility study. U.S. Environmental Protection Agency. 2009.

31. Hunt, E. and B. Butman. Marine engineering economics and cost analysis. Cornell Maritime Press, Centreville, Maryland. 1995.

32. Wonchala, J., M. Hazledine, and K. Goni Boulama, Solution procedure and performance evaluation for a water- $\mathrm{LiBr}$ absorption refrigeration machine. Energy, 2014. 65: p. $272-284$.

33. Talukdar, K. and T.K. Gogoi, Exergy analysis of a combined vapor power cycle and boiler flue gas driven double effect water-LiBr absorption refrigeration system. Energy Conversion and Management, 2016. 108: p. 468-477.

34. Gogoi, T.K. and K. Talukdar, Thermodynamic analysis of a combined reheat regenerative thermal power plant and water-LiBr vapor absorption refrigeration system. Energy Conversion and Management, 2014. 78: p. 595-610.

35. Mortazavi, A., et al., Enhancement of APCI cycle efficiency with absorption chillers. Energy, 2010. 35(9): p. 3877-3882.

36. Palacín, F., C. Monné, and S. Alonso, Improvement of an existing solar powered absorption cooling system by means of dynamic simulation and experimental diagnosis. Energy, 2011. 36(7): p. 4109-4118.

37. Bunkerworld. Fuel prices. 2018. Available: http://www. bunkerworld.com/prices/ (Accessed 2 Sep. 2018).

38. Banawan, A.A., M.M. El Gohary, and I.S. Sadek, Environmental and economic benefits of changing from marine diesel oil to natural-gas fuel for short-voyage highpower passenger ships. Proceedings of the Institution of Mechanical Engineers Part M-Journal of Engineering for the Maritime Environment, 2010. 224(M2): p. 103-113.

39. ICF. Current methodologies in preparing mobile source portrelated emission inventories. U.S. Environmental Protection Agency. 2009.
40. Gupta, A., et al., Economic and thermodynamic study of different cooling options: A review. Renewable and Sustainable Energy Reviews, 2016. 62: p. 164-194.

41. Mikelis, N.E., A statistical overview of ship recycling. J. Marit. Affairs, 2008. 7(1): p. 227-239.

\section{CONTACT WITH THE AUTHORS}

\author{
Naderr Ammar \\ e-mail: eng.naderr@gmail.com
}

Department of Naval Architecture and Marine Engineering Faculty of Engineering Alexandria University 21544 Alexandria

\section{EGYPT}

\section{Ibrahim Sediek}

e-mail:prof.isibrahim@gmail.com

Department of Marine Engineering Technology Faculty of Maritime Transport \& Technology Arab Academy for Science, Technology \& Maritime Transport 1029 Alexandria

\section{EGYPT}

